\title{
Nodulation in Dimorphandra wilsonii Rizz. (Caesalpinioideae), a Threatened Species Native to the Brazilian Cerrado
}

\author{
Márcia Bacelar Fonseca ${ }^{1}$, Alvaro Peix ${ }^{2}$, Sergio Miana de Faria ${ }^{3}$, Pedro F. Mateos ${ }^{4}$, Lina P. Rivera ${ }^{4}$, \\ Jean L. Simões-Araujo ${ }^{3}$, Marcel Giovanni Costa França ${ }^{1}$, Rosy Mary dos Santos Isaias ${ }^{1}$, Cristina Cruz ${ }^{5}$, \\ Encarna Velázquez ${ }^{4}$, Maria Rita Scotti ${ }^{1}$, Janet I. Sprent ${ }^{6}$, Euan K. James ${ }^{7}$ *
}

1 Depto de Botânica, Universidade Federal de Minas Gerais, Belo Horizonte, Minas Gerais, Brazil, 2 Instituto de Recursos Naturales y Agrobiología, IRNASA-CSIC, Unidad Asociada Universidad de Salamanca-CSIC 'Interacción Planta-Microorganismo', Salamanca, Spain, 3 Embrapa Agrobiologia, Seropédica, Rio de Janeiro, Brazil, 4 Departamento de Microbiología y Genética-CIALE, Universidad de Salamanca, Unidad Asociada Universidad de Salamanca-CSIC 'Interacción Planta-Microorganismo', Salamanca, Spain, $\mathbf{5}$ Universidade de Lisboa, Faculdade de Ciências, Centro de Biologia Ambiental (CBA), Lisboa, Portugal, 6 Division of Plant Sciences, University of Dundee at James Hutton Institute, Dundee, United Kingdom, 7 James Hutton Institute, Dundee, United Kingdom

\begin{abstract}
The threatened caesalpinioid legume Dimorphandra wilsonii, which is native to the Cerrado biome in Brazil, was examined for its nodulation and $\mathrm{N}_{2}$-fixing ability, and was compared with another, less-threatened species, D. jorgei. Nodulation and potential $\mathrm{N}_{2}$ fixation was shown on seedlings that had been inoculated singly with five bradyrhizobial isolates from mature D. wilsonii nodules. The infection of D. wilsonii by two of these strains (Dw10.1, Dw12.5) was followed in detail using light and transmission electron microscopy, and was compared with that of $D$. jorgei by Bradyrhizobium strain SEMIA6099. The roots of $D$. wilsonii were infected via small transient root hairs at $42 \mathrm{~d}$ after inoculation (dai), and nodules were sufficiently mature at 63 dai to express nitrogenase protein. Similar infection and nodule developmental processes were observed in $D$. jorgei. The bacteroids in mature Dimorphandra nodules were enclosed in plant cell wall material containing a homogalacturonan (pectic) epitope that was recognized by the monoclonal antibody JIM5. Analysis of sequences of their rrs (16S rRNA) genes and their ITS regions showed that the five $D$. wilsonii strains, although related to SEMIA6099, may constitute five undescribed species of genus Bradyrhizobium, whilst their nodD and nifH gene sequences showed that they formed clearly separated branches from other rhizobial strains. This is the first study to describe in full the $\mathrm{N}_{2}$-fixing symbiotic interaction between defined rhizobial strains and legumes in the sub-family Caesalpinioideae. This information will hopefully assist in the conservation of the threatened species $D$. wilsonii.
\end{abstract}

Citation: Fonseca MB, Peix A, de Faria SM, Mateos PF, Rivera LP, et al. (2012) Nodulation in Dimorphandra wilsonii Rizz. (Caesalpinioideae), a Threatened Species Native to the Brazilian Cerrado. PLoS ONE 7(11): e49520. doi:10.1371/journal.pone.0049520

Editor: Paul V. A. Fine, University of California, Berkeley, United States of America

Received April 23, 2012; Accepted October 9, 2012; Published November 19, 2012

Copyright: (c) 2012 Fonseca et al. This is an open-access article distributed under the terms of the Creative Commons Attribution License, which permits unrestricted use, distribution, and reproduction in any medium, provided the original author and source are credited.

Funding: This work was partly funded by CAPES grant 2127/09-1 (www.capes.gov.br) and by CSIC grant AGL2008-03360 (www.csic.es), which provided a JAEpredoc scholarship. The funders had no role in study design, data collection and analysis, decision to publish, or preparation of the manuscript.

Competing Interests: The authors have declared that no competing interests exist.

* E-mail: euan.james@hutton.ac.uk

\section{Introduction}

The Leguminosae (Fabaceae) is the third largest family of dicotyledonous plants with around 19,000 species that are generally divided into three subfamilies: Caesalpinioideae, Mimosoideae, and Papilionoideae [1]. Although most members of subfamilies Mimosoideae and Papilionoideae are able to associate with soil bacteria to form $\mathrm{N}_{2}$-fixing root (and occasionally stem) nodules, very few genera of the Caesalpinioideae are known to nodulate [2], Those few that do belong to the tribes Cassieae and Caesalpinieae [2]; in tribe Cassieae only Chamaecrista is known to be able to form nodules, but in tribe Caesalpinieae Campsiandra, Chidlowia, Dimorphandra, Erythrophleum, Melanoxylon, Moldenhawera and Tachigali have nodulating species $[2,3,4,5]$.

Infection of legume roots by nodulating bacteria (collectively termed rhizobia) and nodule development has been studied in detail for a very few species of papilionoid and even fewer mimosoid legumes, but there are no published reports on the infection of any caesalpinioid species [6]. There is also a paucity of information about caesalpinioid nodule development, but it is known that of the two general types of legume nodules, those with limited growth (determinate) and those that retain meristematic activity (indeterminate), all nodules so far studied from caesalpinioid legumes are indeterminate $[7,8]$. In addition, it is also known that although in most papilionoid and all mimosoid species, rhizobia are usually released into membrane bound vesicles called symbiosomes [9], those in a few papilionoid and all nodulated caesalpinioid trees remain confined within modified infection threads termed "persistent infection threads" or "fixation threads" $[6,7,10]$, in which it is assumed (but not yet demonstrated) that they fix $\mathrm{N}_{2}$.

In this context, the present study focuses on infection and nodulation of the rare caesalpinioid species Dimorphandra wilsonii Rizz., and its associated microsymbionts. The genus Dimorphandra contains 26 species, all of which are trees native to South America, and although it was known that 11 of these species are nodulated, 


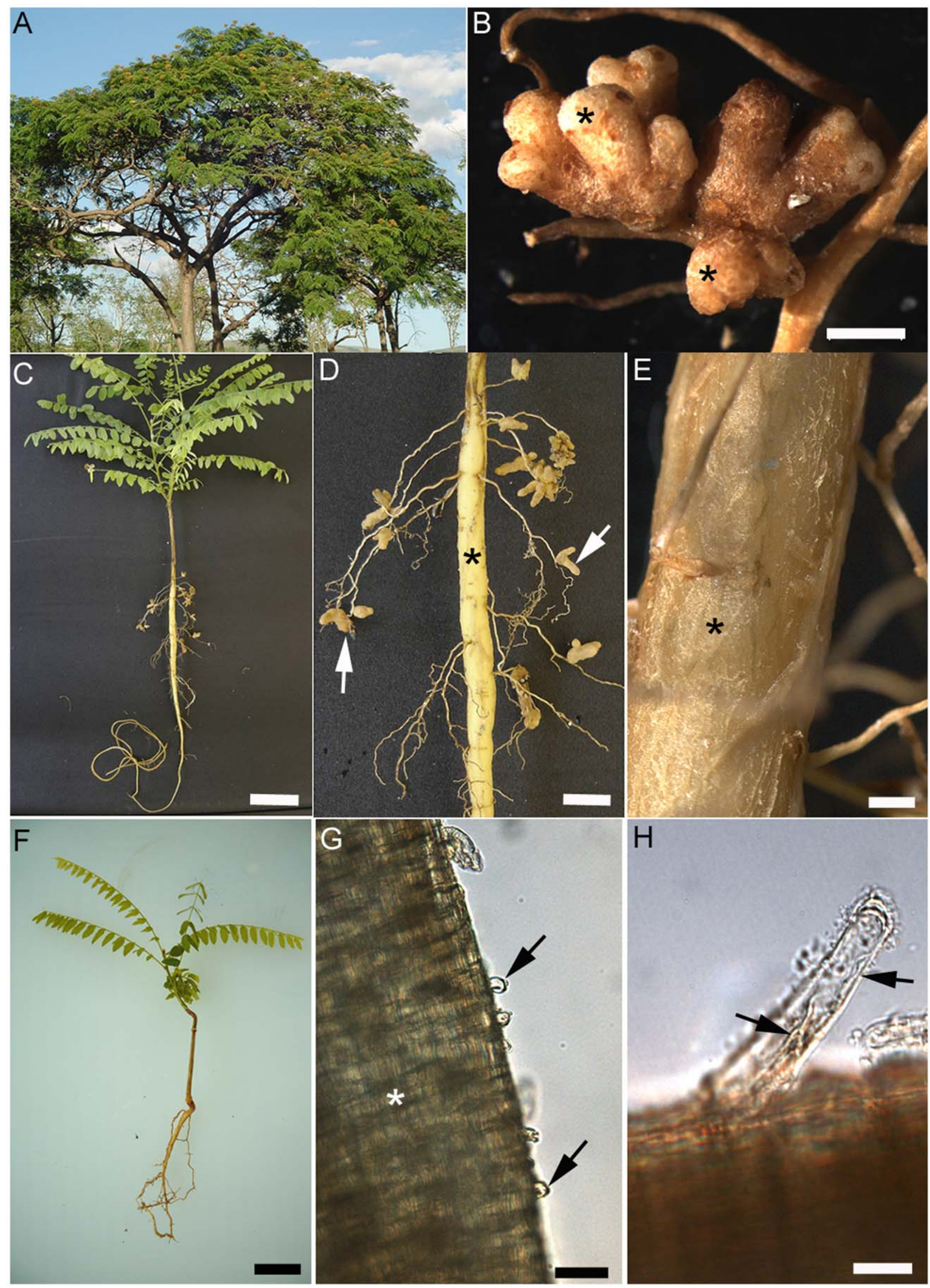


Figure 1. Dimorphandra wilsonii, a nodulated caesalpinioid legume native to Central Brazil. (A) Dimorphandra wilsonii tree growing in a Cerrado reserve at the Zoo-Botanical Garden, Belo Horizonte, MG, Brazil. (B) Nodules (n) from a D. wilsonii plant grown in a Leonard Jar using soil collected from the rhizosphere of adult trees. Twenty two rhizobial strains were isolated from nodules like these, tested for their ability to promote the growth of $D$. wilsonii under $\mathrm{N}$-free conditions, and the five best performing strains (DW3.1, DW6.4, DW8.5, DW10.1, DW12.5) were selected for further examination. (C) Nodulated plant at 120 days after inoculation (dai) with rhizobial strain DW12.5. Note that the plant is green and healthy. (D) Detail of nodulated $D$. wilsonii root showing a swollen tap root $\left(^{*}\right)$, and large elongated nodules (arrows) on the fine lateral roots. (E) Detail of a swollen $D$. wilsonii tap root. Note the thick layer of spongy material $\left.{ }^{*}\right)$. $(\mathrm{F})$ Uninoculated $D$. wilsonii plant grown without any added nitrogencontaining fertilizer. This plant was harvested at the same time as that shown in (B). It had no nodules, and was showing signs of $\mathrm{N}$-deficiency (i.e. yellowing leaves). (G) Light micrograph of short root hairs (arrows) on a D. wilsonii lateral root ${ }^{*}$ ) at 42 dai with strain DW12.5. (H) Light micrograph of a longer root hair (arrow) at 42 dai with strain DW12.5. Note that it appears to contain an infection thread (IT) (arrows). Bars, $3 \mathrm{~mm}$ (B), $3 \mathrm{~cm}$ (C), $1 \mathrm{~cm}$ (D), $2 \mathrm{~mm}(\mathrm{E}), 2 \mathrm{~cm}(\mathrm{~F}), 100 \mu \mathrm{m}(\mathrm{G}), 10 \mu \mathrm{m}(\mathrm{H})$.

doi:10.1371/journal.pone.0049520.g001

prior to the present study the nodulation status of $D$. wilsonii was unknown [2]. Although most Dimorphandra species (e.g. D. exaltata, $D$. jorgei and D. mollis) are widespread and not considered to be threatened [11], some are highly endemic and becoming increasingly rare e.g. D. wilsonii is confined to seasonally dry tropical forests in highland areas of Minas Gerais state in the Brazilian Cerrado [12], and is one of a group of species whose habitat has been destroyed by agricultural development and clearing of areas for cattle-pasture and production of charcoal [13]. This has been graphically demonstrated in recent years by Rizzini and Matos Filho [14], who found only 18 individuals in Minas Gerais $\left(19^{\circ} 16^{\prime} \mathrm{S}, 44^{\circ} 24^{\prime} \mathrm{W}\right)$, and by Fernandes et al. [15] who located another 21 adult individuals in forage areas on two farms in the same area. Therefore, due to the destruction of habitat, very localized area of occurrence, and isolation of its population in remnant areas of the Cerrado, D. wilsonii was included in the Red List of Threatened Species [16] in the category of critically at risk.

There are no published studies on nodulation or $\mathrm{N}_{2}$ fixation in any species of Dimorphandra, but there is some information about their potential rhizobial symbionts. Rhizobia belong to the phylum Proteobacteria, mostly in the alpha class (e.g. Rhizobium, Bradyrhizobium), but some in the beta class (e.g. Burkholderia) $[2,17,18,19]$, and as with their infection and nodulation, relatively little is known about the rhizobia that nodulate caesalpinioid legumes. However, according to the currently available data Bradyrhizobium species may be their preferred endosymbionts [2], and in the specific case of Dimorphandra, two strains found in D. jorgei nodules, Br5004 (SEMIA6099) and Br5005 (SEMIA6400) [5,20], were provisionally identified as Bradyrhizobium elkanii [21,22,23], as was a strain isolated from $D$. parviflora nodules [24]. However, it should be noted that (1) none of these strains were shown to nodulate their Dimorphandra hosts in these studies, and (2) that strains in other rhizobial species, such as Rhizobium and Ensifer (Sinorhizobium), have also been isolated from Dimorphandra nodules [24].

Therefore, the aims of this study are to: (1) determine the nodulation status of the rare legume $D$. wilsonii under natural and laboratory conditions, (2) to identify and characterize the rhizobia associated with $D$. wilsonï, and (3) to follow the infection and development of $\mathrm{N}_{2}$-fixing nodules on $D$. wilsonii roots by defined rhizobial strains, and to compare this with the infection of the widespread species, D. jorgei, by Bradyrhizobium strain SEMIA6099.

\section{Results}

\section{Nodulation by Soil-grown and Inoculated D. wilsonii}

Soil was taken from the rhizosphere of nodulated Dimorphandra wilsonii growing in a reserve in the Cerrado (Figure 1A). "Trap" plants grown in the Cerrado soil were well nodulated, with large branched nodules (Figure 1B). Evidence for nodulation by $D$. wilsonii with specific rhizobial strains came from greenhouse experiments with plants that had been inoculated separately with five strains isolated from the nodulated trap plants. Inoculation with these strains resulted in nodulation of all the inoculated plants by the time that they were harvested at 120 days after inoculation (dai) (Figure 1C), with nodules forming on lateral roots (Figure 1D) that formed from a thick spongy tap root (Figure 1E). The average number of nodules per plant for each strain were $5 \pm 1.08$ (DW12.5), $7 \pm 1.03$ (DW3.1), $11 \pm 1.09$ (DW6.4), $15 \pm 0.83$

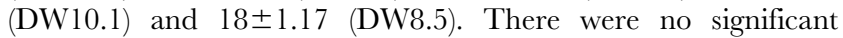
differences between the strains in terms of number of nodules per plant: uninoculated plants had no nodules. The nodulated plants (Figure 1C) were also visibly greener and healthier than the nonnodulated control plants (Figure 1F), and at harvest were twice the height of the uninoculated plants (Figure 1C, F). Close examination of nodulated lateral roots at 60 dai revealed very short root hairs (Figure $1 \mathrm{G}$ ), and some longer ones which appeared to contain infection threads (Figure $1 \mathrm{H}$ ). No root hairs could be observed on the spongy tap roots (Figure 1E).

None of the $D$. wilsonii strains could nodulate soybean, with the exception of strain DW10.1 which produced an average of 5 nodules per plant. This compares with an average of 29 nodules per plant with B. elkanii $29 \mathrm{~W}$, a commercial strain used to inoculate soybean in Cerrado soils. The nodulation data were reflected in the plant dry weights, which, with the exception of plants inoculated with the commercial strain, 29W, were not significantly different to uninoculated controls (data not shown).

\section{Infection and Development of Nodules on D. wilsonii After Inoculation with Bradyrhizobium Strains}

The infection and development of nodules on $D$. wilsonii is shown in Figure 1-4), and that of $D$. jorgei in Figure 5. No root hairs were observed on any of the inoculated or uninoculated plants until 42 dai, at which time small root hairs (Figure $1 \mathrm{G}, \mathrm{H}$ ), some containing infection threads (ITs) could be seen on lateral roots of D. wilsonii inoculated with either Bradyrhizobium strain DW10.1 or DW12.5 (Figure 1H, 2A-D). Small swellings close to the infected root hairs on these roots were shown by light microscopy and TEM to be developing nodule primordia (Figure 2C). Under laboratory conditions, the infection of $D$. wilsonii roots with either strain DW10.1 or DW12.5 thus appears to commence at some point just a few days prior to 42 dai, and coincides with the first appearance of root hairs. The infection process clearly involves the invasion of root hairs and/or adjacent epidermal cells, and the subsequent formation of ITs within them (Figure 2A-D). After this initial epidermal infection the bacteria progress further into the root cortex towards the emerging nodule meristem by invading the cortical cells in a somewhat "disorganized" manner via swollen ITs (Figure 2D, E); these thick-walled ITs move deeper into the root cortex, cell by cell, releasing bacteria into the cortical cells in thin-walled infection "pockets" (Figure 2E). The cortical cells thus invaded do not appear to tolerate the presence of such large numbers of bacteria (even though the bacteria are surrounded by cell wall material), and 
begin to senesce, as evidenced by degraded cytoplasm and the lack of any obvious organelles (Figure 2E). The infection continues into the adjacent cortical cell via ITs arising from the mass of wallbound bacteria (not shown for D. wilsonii, but can be seen in $D$. jorgei; Figure $5 \mathrm{~F}$ ). The remnants of the infection process can be seen in some older nodules as a line of collapsed cortical cells connecting the original point of infection with the developing nodule (Figure 2F), which interestingly, at this stage is surrounded by uninfected cells that contain material that stains blue-green with toluidine blue, and which owing to these staining properties can thus be loosely interpreted as containing "phenolic" substances [25] or tannins [26].

Nodules at various stages of development were observed by 63 dai, ranging from nodule primordia similar to those seen at 42 dai, to mature nodules capable of expressing nitrogenase protein (Figure 3, 4). Smaller (i.e. younger) nodules were generally spherical or oval in morphology, but with a broad apical meristem (Figure 3A). A network of uninfected cells containing phenolic compounds could be observed throughout young nodules, and these cells appeared to delimit "sectors" of 20-30 newly-formed and highly vacuolated cells that were in the process of being infected by rhizobia (Figure 3A, B). In some cases, greatly enlarged intercellular ITs/infection pockets similar to those in Figure 2D, E were observed within these groups of cells (Figure 3G), and cells adjacent to these bacteria were being infected via intercellular ITs (Figure 3C, D). In other groups of cells, intercellular ITs were not obviously present, but the cells contained intracellular ITs adjacent to host cell nuclei (Figure 3E). Some of these ITs were observed releasing rhizobia into thin strands of host cytoplasm but the "released" rhizobia were always observed surrounded by cell wall material, which was quite thin at this early stage of development (Figure 3F).

Structurally, the mature nodules at 63 dai were effective in appearance and typical of nodules on other caesalpinioid legumes $[7,10]$ i.e. indeterminate with an apical meristem, an invasion zone, and an elongated central $\mathrm{N}_{2}$-fixing zone (Figure 4A) consisting of both infected cells and uninfected cells, with many of the latter containing phenolic compounds and/or tannins (Figure 4B, C). The infected cells were larger than the uninfected cells, and they were packed with bacteroids within persistent infection threads ("PITs") of cell wall material (Figure 4B, C). The bacteroids within the PITs were immunogold labeled with an antibody against the nifH protein (Fe-protein), thus indicating that they were expressing this essential component of the nitrogenase enzyme complex (Figure 4D). Serial sections incubated in nonimmune serum substituted for the nitrogenase antibody had no immunogold labeling (data not shown). Nodules were also examined using a monoclonal antibody (JIM5) that recognizes a homogalacturonan epitope in the pectic component of plant cell walls, and which has previously been shown to strongly label the wall of ITs in nodules on pea, as well as other papilionoid legumes [27]. In the present study, JIM5 also labeled invasive ITs very strongly (Figure 4E), but in contrast to pea nodules [27], it also labeled the symbiosomes, specifically the thin walls of the PITs surrounding the bacteroids (Figure 4F). It should be noted, however, that the labeling of the PIT walls was less intense than that observed on the thicker walls of the invasive ITs (Figure 4E).

Very similar data were obtained with $D$. jorgei plants inoculated with Bradyrhizobium strain SEMIA6099 (BR5004), and the whole developmental process could be observed by 60 dai. First, root hairs adjacent to developing nodule primordia were infected (Figure 5A, B) and massively colonized by the bradyrhizobia (Figure 5C, D). The bacteria within these then invaded cortical cells via ITs (Figure 5E), within which they established large, wall- bound "pockets", the presence of which appeared to result in the senescence and collapse of the host cells (Figure 5F). However, as with $D$. wilsonii (Figure 3), the newly-divided cells in young $D$. jorgei nodules were able to receive the invasive ITs without them triggering host cell senescence (Figure 5G); the ITs subsequently released their rhizobia into the host cell cytoplasm, but they remained bound in plant cell wall material (Figure 5G). More mature nodules showed that the bacteria filled the host cells in the infected zone (Figure $5 \mathrm{H}$ ), and that as with $D$. wilsonii they were enclosed in cell wall-bound PITs within which they were presumed to have fixed $\mathrm{N}_{2}$ (Figure 5I).

\section{Identification and Molecular Characterization of $D$. wilsonii Rhizobia via their rrs Gene (16S rRNA) and Internal Transcribed Spacer (ITS) Sequences}

The phylogenetic analysis of the rrs gene of the five strains isolated from Dimorphandra nodules showed their affiliation to genus Bradyrhizobium, forming five independent branches (Figure 6). Four of the five Dimorphandra strains examined in this study (DW3.1, DW6.4, DW8.5, DW12.5) clustered into Bradyrhizobium group I, and the remaining strain, DW10.1, was located within Bradyrhizobium group II (both groups being originally defined by Menna et al. [23]).

Bradyrhizobium group I encompasses phylogenetically close species with similarities ranging from $98.4 \%$, between the type strains of $B$. iriomotense and $B$. denitrificans, to $99.6 \%$, between $B$. japonicum and $B$. liaoningense. To this group also belong some strains isolated from the caesalpinioid species Chamaecrista mimosoides [28] and Tachigali versicolor [29], as well as from the non-legume Parasponia [30]. None of them were the closest relatives to those of the Dimorphandra bradyrhizobial strains (Figure 6). Strain DW3.1 grouped within a wide cluster that also contained the type strains of the recently described species $B$. rifense CTAW7 $1^{\mathrm{T}}$ [31] and $B$. cytisi CTAW $11^{\mathrm{T}}$, the strain BC-C1 of genospecies alpha, as well as other strains isolated from different hosts from diverse geographical locations. The closest relatives to DW3.1 were the strains NGR231 isolated from Parasponia (99.9\% identity) and SEMIA6368 $(99.8 \%$ identity). Also the type strains of $B$. cytisi CTAW $11^{\mathrm{T}}$ and the recently described $B$. rifense CTAW $71^{\mathrm{T}}$ were phylogenetically close with identity values higher than $99.5 \%$. The other three D. wilsonii strains within Bradyrhizobium rrs gene group I (DW6.4, DW8.5 and DW12.5) formed three independent branches within a wide cluster that included several strains isolated from various hosts from several geographical locations (Figure 6). The similarities amongst the D. wilsonii strains were lower than $98 \%$, with $96.5 \%$ between DW12.5 and DW8.5, 97.6\% between DW6.4 and DW8.5, and 97.5\% between DW6.4 and DW12.5. These strains also showed identity values lower than 98.8 and $99.3 \%$ with respect to the two defined species included in this cluster, B. iriomotense $\mathrm{EK} 05^{\mathrm{T}}$ [32] and B. huanghuaihaiense CCBAU $23303^{\mathrm{T}}$ [33], respectively. Considering that many different species comprising Bradyrhizobium group I showed more than $99.5 \%$ similarities in their rrs gene sequences, on the basis of this gene the D. wilsonii strains DW6.4, DW8.5 and DW12.5 could represent three novel species of Bradyrhizobium.

Only one strain examined in this study, DW10.1, clustered within the Bradyrhizobium rrs gene group II, a group in which two strains (SEMIA6400 and SEMIA6099) previously isolated from Dimorphandra jorgei are also located [22,23]. To this group also belongs the strain Cfl isolated from the caesalpinioid species Chamaecrista fasciculata [34] and the strain CP283 isolated from the non-legume Parasponia andersonii [30], with the latter being more closely related to strains from Dimorphandra than the $C$. fasciculata strain (Figure 6). The identities of the three bradyrhizobial strains 


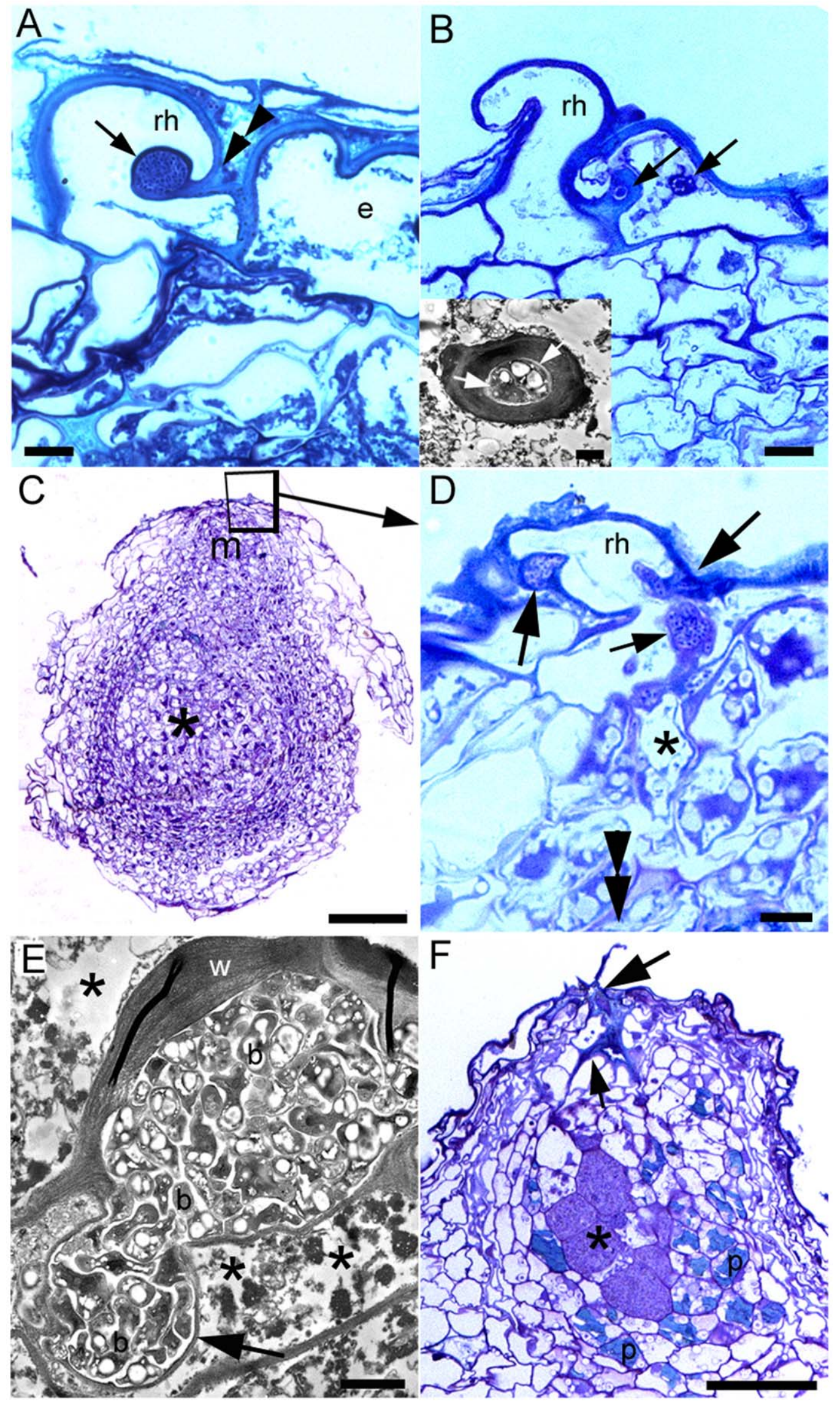


Figure 2. Light microscopy of toluidine blue-stained semi-thin sections (A-D, F) and transmission electron microscopy (TEM) of ultrathin sections (inset in $B, E$ ) illustrating the infection and development of nodules on the lateral roots of $D$. wilsonii at 42 dai with Bradyrhizobium strain DW10.1 (A, F) or DW12.5 (B-E). (A) Short root hair (rh) with an infection thread (IT) containing a large colony of bacteria (arrow). The IT appears to have originated at the inside of a curl in the root hair (double arrowhead). (B) Curled root hair (rh) and adjacent epidermal cell (e). The root hair itself does not appear to have been invaded, but the epidermal cell has been invaded by ITs (arrows, and inset) that appear to have emerged from the cell wall between the two cells. (C) Nodule primordium emerging from a lateral root. The point of infection is at the tip of the nodule (within the region delineated by a square), and is close to the nodule meristem $(\mathrm{m})$. The spherical/oval-shaped main body of the nodule ${ }^{*}$ ) consists largely of newly-infected cells. (D) Detail of the area in the square in panel D showing that the point of infection of the nodule in panel consists of a curled root hair (rh) being subjected to multiple invasions by bacteria (large arrows). These bacteria have then infected the adjacent cortical cells via enlarged ITs (small arrows), before progressing into the root through collapsed/collapsing cortical cells $(*)$ towards the meristem of the emerging nodule primordium (indicated by a double arrowhead). (E) TEM of an enlarged IT in a collapsing root cortical cell located two or three cell layers deeper into the root and approaching the meristem of the emerging nodule (i.e. in the region marked ${ }^{*}$ in panel D). Note that the enlarged IT contains numerous bacteria (b), and also that one side of it is bounded by a thick cell wall (w), whereas the other side has a much thinner cell wall, and appears to be releasing the bacteria into the degraded cytoplasm $\left(^{*}\right.$ ) of the host cell (arrow). (F) Emerging nodule primordium containing a small group of infected cells $(*)$ surrounded by blue-green phenolic-containing cells $(p)$. The remains of the original infection can be seen at the tip of the nodule primordium (large arrow), as can the progression of the infecting bacteria through the root cortex, the remains of which are a line of collapsed host cells (small arrow). Bars, $10 \mu \mathrm{m}$ (A, B, D), $100 \mu \mathrm{m}$ (C), $1 \mu \mathrm{m}$ (B inset, E), $50 \mu \mathrm{m}$ (F).

doi:10.1371/journal.pone.0049520.g002

isolated from Dimorphandra species (DW10.1, SEMIA6400, SEMIA6099) ranged between the type strains of B. jicamae and B. elkanii $(99.5 \%)$ and the type strains of B. elkanii and B. pachyrhizi (100\%). Indeed, strain DW10.1 showed $100 \% \quad 16 \mathrm{~S}$ rRNA sequence identity with respect to the type strains of $B$. elkanii and B. pachyrhizi, but identities of $100 \%$ (or close to $100 \%$ ) are common among species of Bradyrhizobium, and they can only be differentiated on the basis of their ITS sequences (which are linked in most cases to DNA-DNA relatedness; [35]). According to the results of the ITS analysis, Bradyrhizobium species are distributed into two groups coincident with those found after rrs gene analysis (Figure 7). Also in agreement with the results of the rrs gene sequences, the strains from Dimorphandra are located in five branches, with strains DW3.1, DW6.4, DW8.5 and DW12.5 belonging to the ITS group 1, and DW10.1 to ITS group 2.

Strains DW3.1 and DW8.5 belong to the same ITS subgroup (Figure 7) that also contains strains isolated in different geographical locations from various hosts (see Figure 7). The internal identities of this subgroup, calculated after pairwise analysis and without gaps, are low, with 96.4\% identity, between strains DW8.5 and TUXTLAS-231722 $\mathrm{m}$ isolated from siratro (Macroptilium atropurpureum) [36] and 96.3\% between DW3.1 and SEMIA 6014, which was isolated from Stylosanthes (96.3\% identity). They have 93.2 and $94.1 \%$ identity, respectively, to the type strain of $B$. yuanmingense, their closest relative in terms of described Bradyrhizobium species. Considering that strains from the same Bradyrhizobium species with more than 95\% identity in the ITS fragment are in the same species [35], DW3.1 thus most probably represents an undescribed species of Bradyrhizobium, as does strain DW8.5.

Rhizobial strains DW6.4 and DW12.5 were the most closely related of the five $D$. wilsonii strains on the basis of their rrs gene sequences (Figure 6), but as their ITS sequences are only $93.2 \%$ identical they probably belong to different species. Indeed, they both cluster in different ITS subgroups, in which no described Bradyrhizobium species are present (Figure 7). However, both subgroups contain other strains that were isolated in the Americas, including strain 8v from genospecies TUXTLAS-11 isolated from Vigna in N. America [36], which probably is the same species as DW6.4, as their ITS sequences are $99.1 \%$ identical. Strains Aa20103 and $1784 \mathrm{~m}$ from genospecies TUXTLAS-12 [36] are closely related to DW12.5, with $98.1 \%$ and $98.0 \%$ identity values, respectively, and it is, therefore, likely that these three strains belong to the same species. These two putatively novel species (one including strains DW6.4 and $8 \mathrm{v}$, and the other one containing strains DW12.5, Aa20103 and $1784 \mathrm{~m}$ ) are also very different to those currently described in genus Bradyrhizobium, since the closest relative species are $B$. iriomotense and $B$. yuanmingense (branching in other ITS subgroups), with identity values of 93.9 and $93.8 \%$, respectively, in relation to strain DW6.4, and 91.8 and $92.5 \%$, respectively, in relation to strain DW12.5 (Figure 7).

The D. wilsonii bradyrhizobial strain DW10.1 (which is in rrs gene group II) belongs to an ITS subgroup supported by a bootstrap of $99 \%$ that includes the type strains of $B$. elkanii USDA $76^{\mathrm{T}}$, which was isolated from soybean nodules, B. lablabi which was isolated from Lablab purpureus [37], and B. pachyrhizi PAC48 $^{\mathrm{T}}$ and B. jucamae PAC68 ${ }^{\mathrm{T}}$, which were isolated from Pachyrhizus nodules [38]. Strains from the genospecies $\times$ and XI of [35] are close to the aforementioned strains, and together with them they form a wide group that also contains strain SEMIA 6099 which was isolated from Dimorphandra jorgei [5] and which has an identity value of $94.4 \%$ with respect to DW10.1. Interestingly, although SEMIA 6099 (together with strain LMG 11951 from genospecies $\mathrm{XI}$ ), should be classified as B. pachyrhizi, as they have identity values higher than $98.4 \%$, strain DW 10.1 may actually belong to a separate species, as it only has $95.5 \%$ identity with respect to $B$. elkanii USDA $76^{\mathrm{T}}$, which is at the limit for species differentiation in bradyrhizobia [35].

\section{Phylogeny of Symbiosis-related Genes (nifH and nodD) from $D$. wilsonii Rhizobia}

The nodD and nifH genes were sequenced in the same strains used to study the infection process in D. wilsonii, Bradyrhizobium sp. DW10.1 and Bradyrhizobium sp. DW12.5, both clustering into different groups based on rrs and ITS phylogenetical analyses. Analysis of the nodD gene showed that both strains belong to two different lineages with only $75.3 \%$ identity between them (Figure $\mathrm{S} 1)$. The closest related type strain to both strains DW10.1 and DW12.5 was B. jicamae PAC68 ${ }^{\mathrm{T}}$, isolated from Pachyrhizus erosus in Honduras (Central America), with 78.9 and 76.6\% similarities, respectively.

As with their nodD sequences the nifH genes of strains DW10.1 and DW12.5 were divergent (although much less so than their nodD genes), with only $86.3 \%$ similarity between them (Figure S2). The closest related type strain to DW10.1 again was B. jicamae $\mathrm{PAC68}^{\mathrm{T}}$ with $89.5 \%$ identity, but other unclassified strains had higher nifH similarities, such as two Chinese strains isolated from Lablab (CCBAU 61434) and Arachis (CGBAU 23160) both with $99.1 \%$ identity. The nifH gene of strain DW12.5 showed $87.8 \%$ identity with respect to $B$. jicamae PAC68 ${ }^{\mathrm{T}}$ and $86 \%$ identity with respect to the type strain of $B$. canariense, which was isolated in the Canary Islands from tagasaste (Cytisus [syn. Chamaecytisus] proliferus). In addition, CCBAU 65788 isolated in China from Pueraria had a nifH 

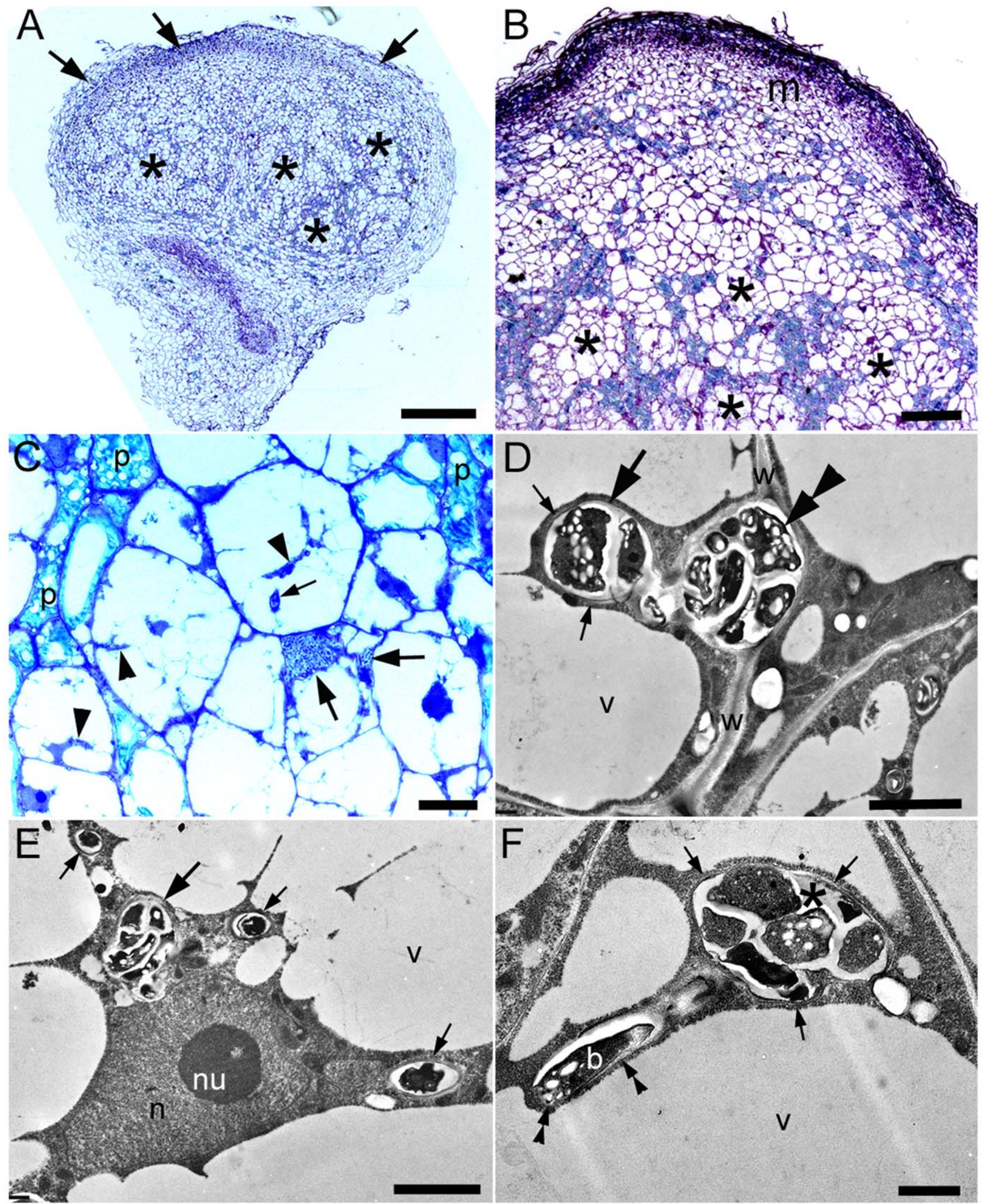

Figure 3. Light microscopy (A-C) and TEM (D, E, F) of developing (i.e. pre-N-fixing) nodules on a $D$. wilsonii root at 63 dai with Bradyrhizobium strain DW12.5. (A) The young nodules are spherical/oval in shape, but a broad apical meristem is still apparent (arrows), as would be expected in an indeterminate nodule. The remainder of the nodule is effectively an "invasion zone", as it is being actively invaded by rhizobia (see subsequent panels), but there are no $\mathrm{N}$-fixing cells containing bacteroids established at this stage. (B) The invasion zone behind the large meristem $(\mathrm{m})$ is divided into "sectors" ${ }^{*}$ ) by files of blue-green phenolic-containing cells. (C) High magnification view of a "sector" within the invasion zone that 
is delimited by phenolic-containing cells ( $p$ ). There are groups of intercellular bacteria (large arrows), and these appear to be the origin of the bacteria in the IT that is infecting the adjacent cell (small arrow). Strands of cytoplasm containing bacteria are indicated by arrow heads. (D) Intercellular bacteria (double arrowhead) within the thick cell walls (w) between two cells; note that an invasive IT (large arrow) has branched from the intercellular bacteria and has started to invade the more vacuolated of the two adjacent cells. Also note the relatively thin cell wall surrounding this invasive IT (small arrows). (E) Cell in a "sector" containing intracellular ITs, the largest of which (large arrow) is associated with the host cell nucleus. The narrower ITs (small arrows), which may have originated from the large one, are contained within thin strands of host cytoplasm. (F) A large intracellular IT ${ }^{*}$ ) that is in the process of releasing bacteria (b) into a host cell. Note that the IT has a cell wall (arrows), as does the bacterium that is in the process of being "released" (double arrowheads) into a thin strand of cytoplasm. $n$, nucleus; nu, nucleolus; v, vacuole. Bars, $500 \mu \mathrm{m}$ (A), $100 \mu \mathrm{m}$ (B), $10 \mu \mathrm{m}(C), 2 \mu \mathrm{m}(\mathrm{D}, \mathrm{E}), 1 \mu \mathrm{m}(\mathrm{F})$.

doi:10.1371/journal.pone.0049520.g003

gene sequence closely related to that of DW12.5, with $91.8 \%$ identity (Figure S2). It is remarkable that the nifH gene of the bradyrhizobial strain Cfl isolated from the caesalpinioid species, Chamaecrista fasciculata [34], was phylogenetically divergent from those of Dimorphandra wilsonii strains (Figure S2) and also from that of strain ANU 289 isolated from Parasponia [39].

\section{Discussion}

\section{Infection and Development of Nodules on D. wilsonii}

Five Bradyrhizobium strains (DW3.1, DW6.4, DW8.5, DW10.1 and DW12.5) that were isolated from $D$. wilsonii nodules were all shown to have the ability to nodulate their host under axenic $\mathrm{N}$-free conditions (i.e. in sand/vermiculite-filled Leonard jars). The two D. wilsonii Bradyrhizobium strains that appeared to be the most effective at nodulation (DW10.1, DW12.5) were examined in more detail for their ability to infect and nodulate D. wilsonii seedlings under controlled conditions. The infection process of $D$. wilsonii by these strains was also compared with that of D. jorgei by another Bradyrhizobium strain, SEMIA6099, which was originally isolated from $D$. jorgei [5]. Both $D$. wilsonii strains were capable of inducing nodules on their host by 42 dai, and both of them infected $D$. wilsonii via root hairs that had formed on their lateral roots by this time. No root hairs were observed on either the thick spongy tap roots or on the lateral roots in the weeks prior to the 42 dai harvest. This is not unprecedented, as several woody legumes are known not to produce root hairs at all, and by definition these must nodulate through a non-root hair infection process [40]. However, in the case of $D$. wilsonii, although root hairs are actually produced, in our experimental set up their appearance was delayed until just a few days prior to 42 dai, and this delay would thus explain the initiation of nodules at such a relatively late stage after the seedlings were inoculated. The late formation of root hairs and the subsequent delayed development of nodules on $D$. wilsonii might be related to nutrient acquisition, as it is well known that the large seeds of legume trees contain substantial reserves of $\mathrm{N}$ (and other nutrients) [40], and thus there is less urgency for seedlings to initiate the nodulation process (or indeed to produce root hairs) immediately after germination.

In soybean and most other legumes so far examined with a root hair infection $[9,40,41]$, rhizobia are conveyed from the hair to the nodule primordium through tubular, cell wall-bound ITs. The latter penetrate the newly-divided nodule cells, and the rhizobia are then released from the ITs into the host cytoplasm via unwalled infection droplets, upon which they are endocytosed by being immediately surrounded by a host-derived plasma membrane (the "symbiosome membrane"). Once enclosed within these "symbiosomes" the rhizobia then begin their transition into symbiotic N-fixing bacteroids. The symbiosome is effectively an organelle that creates an environment allowing for the optimization of $\mathrm{N}$-fixation by the rhizobial bacteroids, and the symbiosome membrane mediates the efficient exchange of fixed $\mathrm{N}$ from the bacteroids for $\mathrm{C}$ containing compounds from the host [42].

In the case of Dimorphandra, the steps in the $D$. wilsonii and $D$. jorgei nodulation processes were generally similar to those reported for crop legumes nodulated by Bradyrhizobium, such as soybean [41], rather than the processes involving crack entry and/or intercellular bradyrhizobia described for tagasaste [43] and Lupinus albus [44]. The main difference to the aforementioned process in soybean (and most other described legumes) is that the initial root hair infection was more "aggressive" in the Dimorphandra species. It also involved the relatively large scale and somewhat disorganized invasion of adjacent epidermal and cortical cells via large ITs, and the subsequent formation of large wall-bound pockets within these cells, which upon being invaded then senesced as the bacteria moved deeper into the root towards the developing nodule meristem via further enlarged ITs.

In common with other caesalpinioid legumes [7,10], a few papilionoid legumes, but no mimosoid species [40], and with the non-legume Parasponia (family Cannabaceae in the order Rosales) $[45,46,47]$, the rhizobia in $D$. wilsonii and $D$. jorgei nodules remain enclosed in host cell wall material after they are released into the newly-divided cells from the invasive ITs. These plant cell wallbound structures are termed "persistent infection threads" (PITs) or "fixation threads" [40,46], and this study has shown that in common with "normal" invasive ITs [27] the PITs in Caesalpinioid legumes are, indeed, surrounded by material that contains homogalacturonan epitopes (recognized by the monoclonal antibody JIM5) that are also present in the pectic middle lamella of plant cell walls [27]. The present study has also shown for the first time that the bacteroids within PITs are capable of expressing nitrogenase protein, of fixing atmospheric $\mathrm{N}_{2}$, and transferring the fixed $\mathrm{N}$ to the host. How this is achieved in PIT-containing legumes (and Parasponia) apparently without the complex biochemical and anatomical aspects of the highly evolved symbiosome membrane $[9,42]$, and with the additional barrier of a cell wall surrounding the bacteroids is a subject worthy of further investigation. Even though the JIM5-labeled walls of the PITs are considerably thinner than those of normal ITs, they are still likely to impede both the diffusion of both gases and solutes, and thus negatively affect the efficiency of the symbiosis, and so it is relevant to pose the question as to why bacteroids are enclosed in PITs in these symbioses? In the specific case of Dimorphandra spp. and bradyrhizobia, a clue to this might lie in the quasi-pathogenic infection process involving the senescence and collapse of invaded root cells (epidermal and cortical). This suggests that the relationship between the two partners in the symbiosis is not completely stable, and thus necessitates the invading rhizobia being kept enclosed in cell wall material at every stage of the nodulation process, even including when they are within the more "compatible" cells of the nodule itself. Interestingly, a similar "quasi-parasitic" relationship was recently decribed by Op den Camp et al. [47] for the interaction of some rhizobial strains with the non-legume Parasponia andersonii, which also forms a symbiosis 


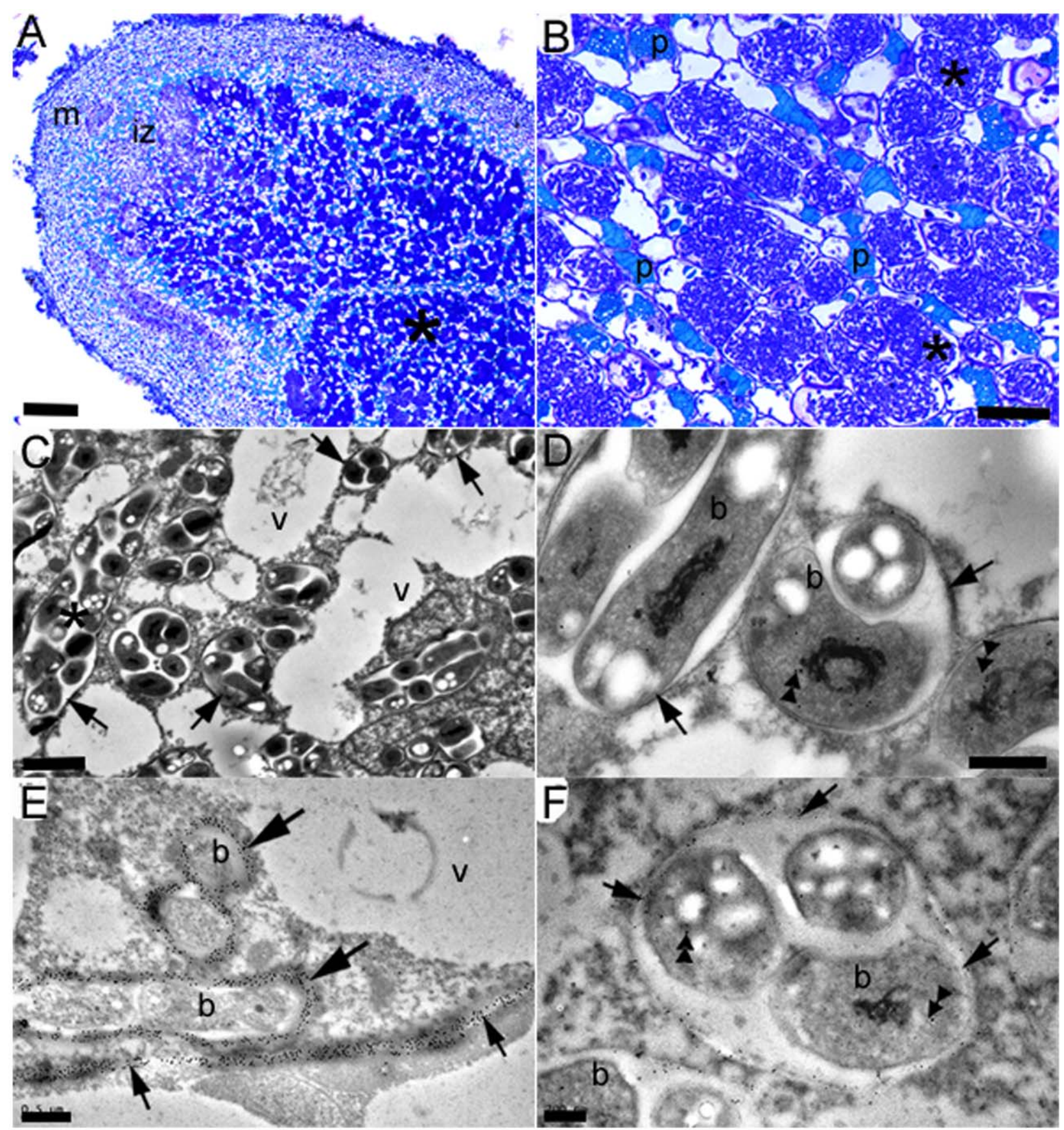

Figure 4. Light microscopy (A, B) and TEM (C-F) of mature, N-fixing D. wilsonii nodules at 63 dai with Bradyrhizobium strains DW12.5 (A-C, E) or DW10.1 (D, F). (A) Longitudinal section of a lobe from a large branched nodule shows the typical zonation of an indeterminate nodule, with an apical meristem (m), an invasion zone (iz) and a large infected $\mathrm{N}$-fixing zone ${ }^{*}$ ). Note the file of uninfected cells in the infected zone that contain phenolic compounds (arrow). (B) High magnification light micrograph of the infected zone shows the infected cells $(*)$ to be filled with persistent infection threads (PITs), and to be interspersed with uninfected, phenolic-containing cells (p). (C) More detail of the infected cells can be seen under the TEM, where groups of bacteria, up to 15 per symbiosome $\left(^{*}\right.$ ), are enclosed in cell walls (arrows). v= vacuole. (D) Immunogold labeling of the nodules with an antibody against the nifH protein (Fe-protein) shows that the bacteroids (b) within the PITs/symbiosomes express this essential component of the nitrogenase enzyme complex (double arrowheads). Note the cell wall material surrounding the symbiosomes (arrows). (E) Infection threads in the invasion zone; note that the walls of these are strongly immunogold labeled with JIM5 (large arrows), a monoclonal antibody that recognizes a homogalacturonan epitope in pectin, which is a major component of plant cell walls. Note that the cell wall separating the infected cell from its neighbor is also strongly labeled (small arrows). $\mathrm{b}=$ bacteria, $\mathrm{v}=$ vacuole. (F) Persistent infection threads within the $\mathrm{N}$-fixing zone: the walls of these are also immunogold labeled with JIM5 (arrows), thus confirming that the bacteroids (b) which are expressing nifH protein (double arrowheads) are also surrounded by cell wall material. Note, however, that the JIM5-labeled PIT walls are considerably thinner than those enclosing the invasive infection threads in (E). Serial sections to $(D, E, F)$ that were treated with non-immune serum substituted for either the nifH protein or JIM5 antibodies showed no labeling (not shown). Bars, $200 \mu \mathrm{m}$ (A), $20 \mu \mathrm{m}$ (B), $2 \mu \mathrm{m}$ (C), $500 \mathrm{~nm}(\mathrm{D}, \mathrm{E}), 200 \mathrm{~nm}(\mathrm{~F})$. doi:10.1371/journal.pone.0049520.g004 


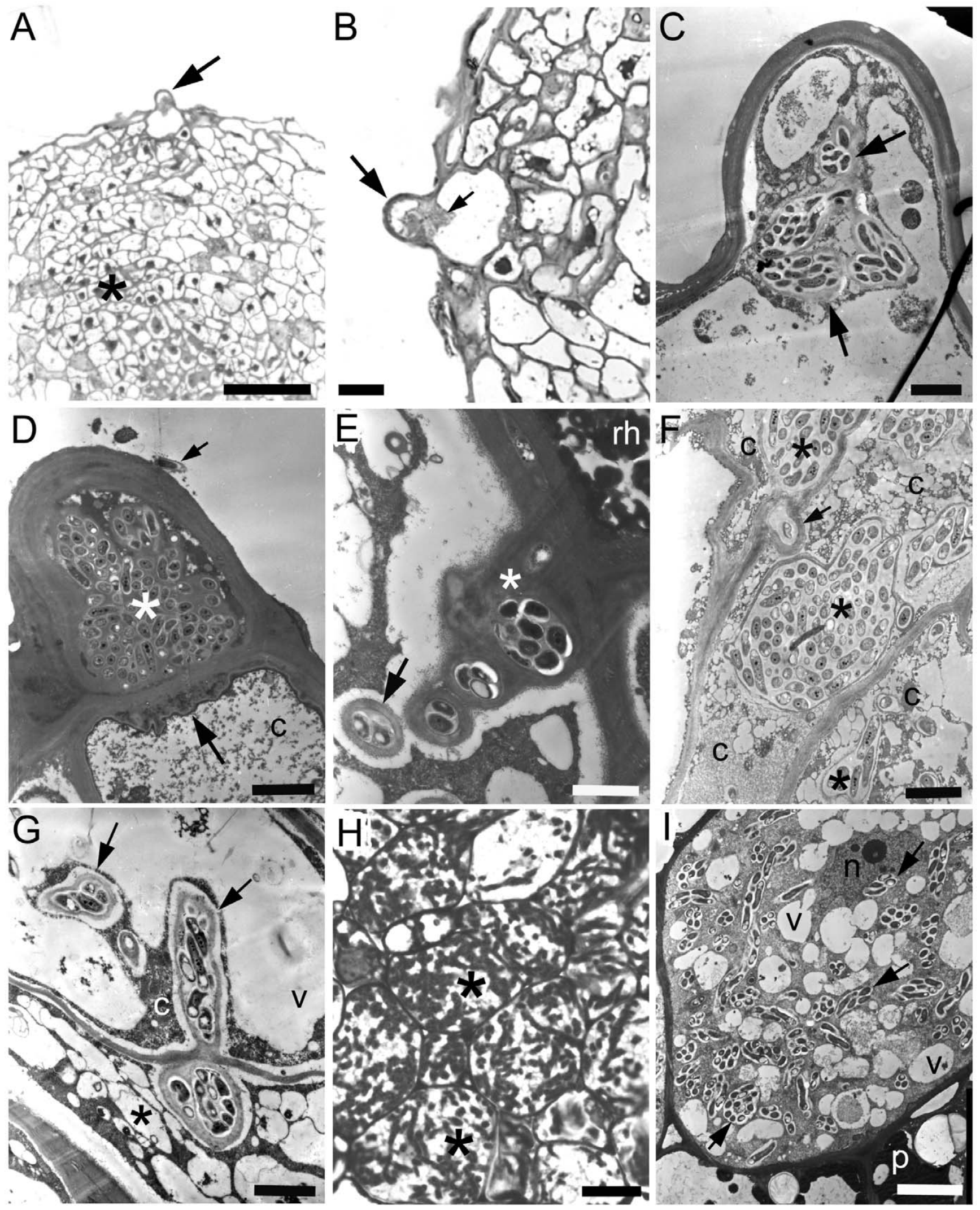

Figure 5. Light microscopy (A, B, H) and TEM (C-G, I) of the infection and development of $\mathbf{N}$-fixing nodules on $D$. jorgei. These micrographs are of samples taken from nodulated roots at 60 dai with Bradyrhizobium elkanii strain SEMIA6099. (A) Root hair (arrow) at the tip of a nodule primordium consisting of newly-divided cells $(*)$. (B) Higher magnification of the root hair (large arrow) showing that it appears to have been infected (small arrow). (C) Detail of the root hair confirming that it has been infected with bacteria; note that the bacteria are surrounded by a thick cell wall (arrows). (D) A root hair that is almost completely filled with bacteria that are embedded in an electron-dense matrix $\left(^{*}\right)$. There is a bacterium 
attached to the surface of the root hair (arrow), and note that the protrusion on the cell wall that is common to the adjacent cortical cell (c) appears to be the precursor of an invagination by the bacteria in the root hair into the cortical cell (large arrow). (E) Penetration of a cortical cell by an IT that has emerged from the cell wall $\left(^{*}\right)$ between the cortical cell and the adjacent root hair ( $r$ ); bacteria have been released from the IT and they are surrounded by a thick cell wall (arrow). (F) Cortical cells that have been infected by large groups ("pockets") of bacteria that are surrounded by cell wall material $\left(^{*}\right)$. The large cell in the center of this micrograph has been infected via an IT (arrow) that has originated from a bacterial pocket in the adjacent cell at the top of the micrograph. Note that the host cytoplasm (c) is degraded in all the host cells, and that the cell in the center is shrunken in appearance. (G) Infection of a newly-divided nodule primordium cell by an IT (large arrow) that has entered from an adjacent degraded cortical cell $\left.{ }^{*}\right)$. The newly-infected cell is highly vacuolated (v), but the invading IT has been surrounded by intact cytoplasm (c). (H) Mature, $\mathrm{N}$-fixing cells packed with PITs $\left(^{*}\right)$. (I) TEM showing detail of an infected cell containing PITs with 5-10 bacteroids in each (arrows). The host cell is clearly viable, as can be seen by an intact nucleus ( $\mathrm{n})$. Note the numerous small vacuoles $(v)$, and the adjacent cell which contains electron-dense phenolic material ( $p$ ). Bars, $50 \mu \mathrm{m}(\mathrm{A}), 10 \mu \mathrm{m}(\mathrm{B}, \mathrm{H}), 2 \mu \mathrm{m}(\mathrm{C}, \mathrm{D}, \mathrm{F}, \mathrm{G}), 1 \mu \mathrm{m}(\mathrm{E}), 5 \mu \mathrm{m}(\mathrm{I})$. doi:10.1371/journal.pone.0049520.g005

with rhizobia that involves the bacteroids being enclosed in PITs $[45,46]$.

\section{Dimorphandra Symbionts are Genetically Distinct from Other Bradyrhizobia According to their rrs genes, ITS Regions and Symbiosis-related Genes}

This study has shown clearly using $r r$ gene and ITS sequences that $D$. wilsonii strains, in common with the only other known characterised Dimorphandra isolates, SEMIA6400 and SEMIA6099 from D. jorgei [22,23], belong to the genus Bradyrhizobium. Four of the D. wilsonii strains (DW3.1, DW6.4, DW8.5, DW12.5) belong to Bradyrhizobium group I, and the remaining one (DW10.1) to Bradyrhizobium group II (along with SEMIA6400 and SEMIA6099), as defined by Menna et al. [23] on the basis of rrs gene analysis. Interestingly, although both groups contain strains isolated from other caesalpinioid legumes none of the $D$. wilsonii strains was particularly closely related to them, or to strains from Parasponia, at least in terms of their rrs sequences.

By using both rrs and ITS sequences our study has been able to more precisely classify the Dimorphandra strains within the genus Bradyrhizobium, and has shown that each of the five strains isolated from $D$. wilsonii nodules may constitute different undescribed species. This is in spite of the fact that D. wilsonii strain DW10.1 has a rrs gene phylogenetically close to SEMIA6099 from $D$. jorgei, which has been identified as a $B$. pachyrhizi strain, and is because DW10.1 and SEMIA6099 have very divergent ITS sequences. Our study also contains the first published description of the symbiosis-essential regulatory nodD gene from symbionts of a caesalpinioid legume. The analysis of both nodD and nifH genes showed that the D. wilsonii Bradyrhizobium strains formed branches clearly separated from other rhizobial genera suggesting that vertical transmission plays a predominant role in the persistence of symbiotic genes in Bradyrhizobium, as was already indicated by studies on bradyrhizobia from other legumes [18,48,49,50]. Interestingly, none of the $D$. wilsonii strains could nodulate soybean (except for strain DW10.1, albeit ineffectively), which suggests that they possibly have a high degree of specificity towards their host. This will be investigated further via analyses of their nodA genes and of their host range on various legumes known to nodulate with bradyrhizobia, including other caesalpinioid legumes.

Taken together, the phylogenetic analysis of housekeeping and symbiosis-related genes suggests a very high diversity of bradyrhizobia nodulating Dimorphandra in tropical seasonally dry ecosystems, such as the Brazilian Cerrado. Interestingly, the symbionts of Mimosa spp. that are endemic to the Cerrado, although they are Burkholderia and not bradyrhizobia as far as has been found to date, are also very diverse and particular to this environment [51]. Indeed, the poor soils, highly seasonal precipitation and fire-dominated ecology of the Cerrado are known to be major reasons for making it a hotspot for legume biodiversity [52] and, presumably also of their associated rhizobial symbionts [51]. Further research into other endemic legumes (in all three sub-families) from this biome should provide a lot of information about co-evolution between legumes and rhizobia in extreme environments that have promoted endemicity [52].

\section{Bradyrhizobia may be the Preferred Symbionts of Caesalpinioid Legumes}

As well as providing detailed information about Dimorphandra symbionts, by comparing their sequences (as far as is possible) with those from rhizobia isolated from other caesalpinioids the present study has also added to our very sparse knowledge about the rhizobial symbionts of caesalpinioid legumes in general. All caesalpinioid nodulating genera, with the exception of Chidlowia and Erythrophleum, which are endemic to West Africa [4], and the large pantropical genus Chamaecrista, are endemic and/or native to South and Central America, with Brazil being a major centre of diversity $[2,5]$. Amongst the nodulating genera in the Caesalpinieae, the present study has confirmed that Dimorphandra spp. are nodulated by Bradyrhizobium [21,22,23,24], and bradyrhizobia have also been isolated from nodules on Melanoxylon [53], Tachigali [24,29]. Campsiandra is possibly nodulated by Burkholderia (Mitchell Andrews, personal communication), but nothing is yet known about symbionts of Moldenhawera. In the case of the African Caesalpiniod genera, Erythrophleum is nodulated by Bradyrhizobium [4], but the symbionts of Chidlowia so far remain unidentified. Finally, with regard to Chamaecrista (Cassieae), although very little is known about what nodulates the 280 plus species in this large genus, among the various rhizobial types that have been isolated from Chamaecrista nodules, bradyrhizobia have been the most commonly isolated genus, as shown by studies in Australia [28], China [54], Senegal [48] and the USA [34], although not, so far in Brazil, which, interestingly, is the centre of radiation of the genus [24].

On the basis of the somewhat sparse evidence so far obtained, it would thus appear that caesalpinioid legumes may have a preference for Bradyrhizobium. Interestingly, bradyrhizobia are also the preferred symbionts of Parasponia [30,48], which is the only non-legume known to form nodules with rhizobia, and which, like so many caesalpinioid legumes, such as Dimorphandra (this study), also encloses them in PITs [45,46,47]. It also appears that bradyrhizobia, which are very ancient symbionts of legumes [55,56], are highly adaptable in terms of their hosts, being capable of forming symbioses with non-legumes (Parasponia), basal (and therefore, "primitive") legumes, such as the Caesalpinioideae (this study), and with "advanced" papilionoid legumes, such as soybean, lupins, and Aeschynomene spp. Bradyrhizobia are also adaptable in their methods of infecting their hosts. Although they often utilize the "classical" root hair pathway, such as in the present study and in other woody legumes, such as the mimosoid species Acacia mangium [26], many bradyrhizobial strains are capable of infecting their hosts via more "exotic" routes, particularly through variations on 


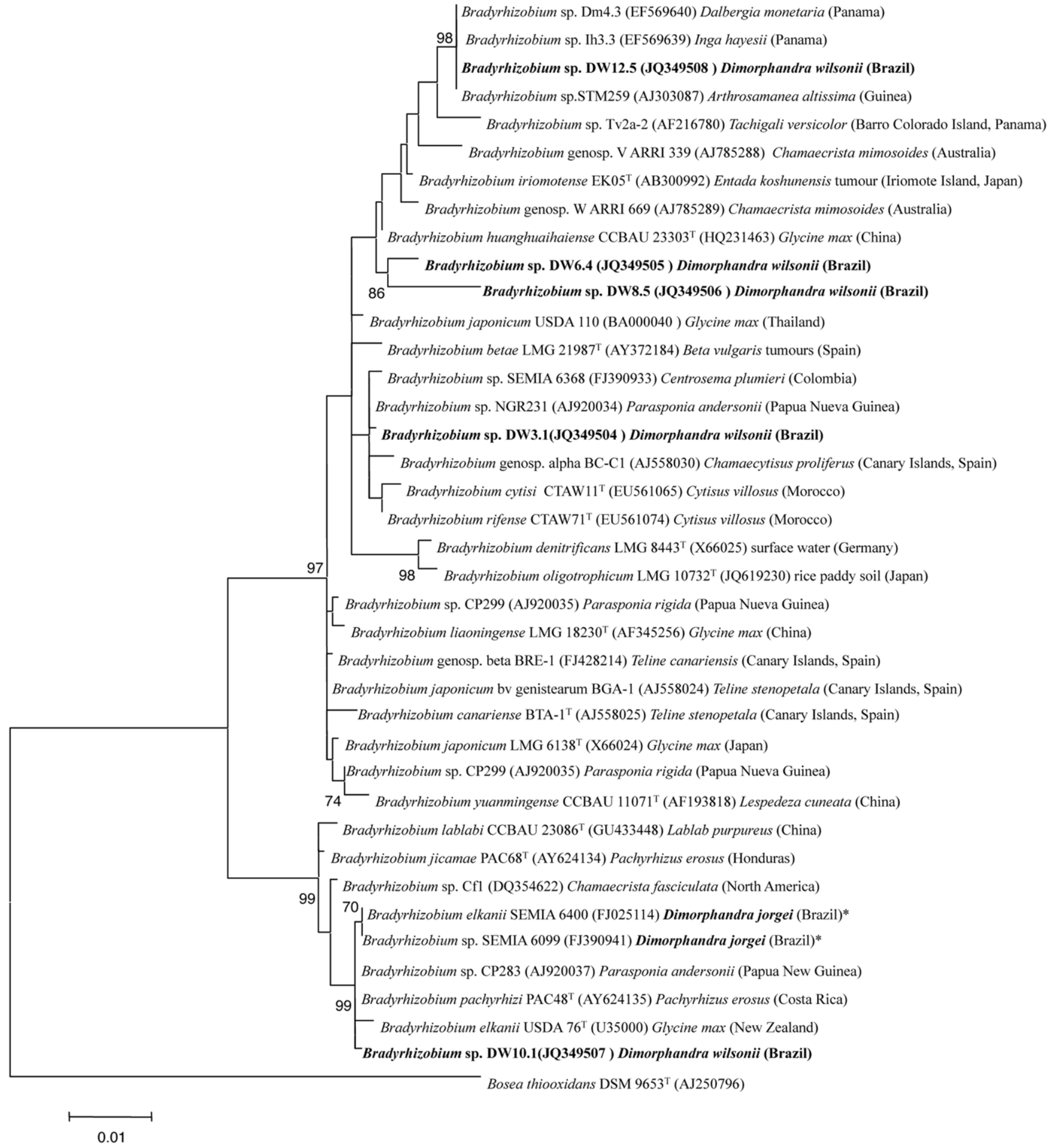

Figure 6. Maximum likelihood phylogenetic tree based on rrs (16S rRNA) gene sequences (1348 nt) showing the position of strains isolated from Dimorphandra wilsonii nodules within the genus Bradyrhizobium. Bootstrap values were calculated for 1000 replications. Bar, $1 \mathrm{nt}$ substitution per $100 \mathrm{nt}$.

doi:10.1371/journal.pone.0049520.g006

"crack entry", as has been shown for tagasaste [43], Lupinus [44] and Aeschynomene spp. [57].

\section{Concluding Remarks}

This study is the first report to describe in full a symbiotic association between a caesalpinioid legume and defined strains of rhizobia, but as with papilionoid legumes, we cannot exclude the possibility that not all caesalpinioid legumes have an infection pathway similar to Dimorphandra, especially considering their separation both in taxonomic terms and in time of nodule evolution [58]. Nevertheless, it does suggest that basal legumes can be infected via root hairs, which is considered a relatively 


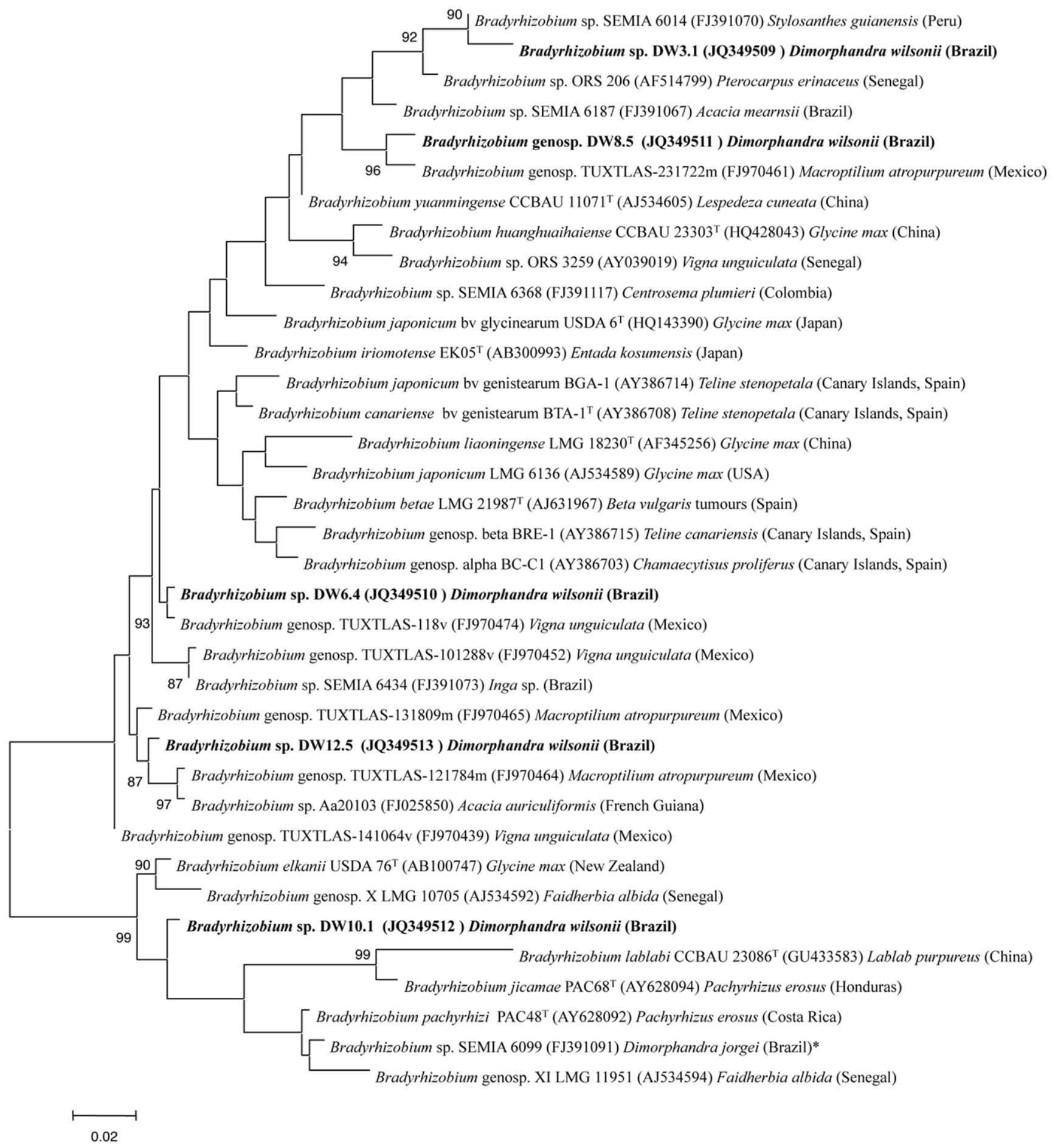

Figure 7. Maximum likelihood phylogenetic tree based on 16S-23S rDNA intergenic spacer (ITS) sequences (604 nt) showing the position of strains isolated from Dimorphandra wilsonii nodules within the genus Bradyrhizobium. Bootstrap values were calculated for 1000 replications. Bar, 1 nt substitution per 100 nt. doi:10.1371/journal.pone.0049520.g007

"advanced" form of infection [2,6], and further studies with other nodulated caesalpinioid legumes are needed to determine how typical such a process is in this paraphyletic sub-family.

The five nodulating strains isolated from $D$. wilsonii nodules that were studied in detail may represent up to five new Bradyrhizobium species, and sequences of the symbiosis-related genes, nif $H$ and nod $D$ suggest that $D$. wilsonii symbionts may be unique amongst the bradyrhizobia. Indeed, this uniqueness could be related to the particular environment within which $D$. wilsonii has evolved i.e. the acidic and low nutrient soils of the seasonally dry savannah of Central Brazil (the "Cerrado"). Understanding more fully how its $\mathrm{N}$-fixing symbiosis can form and operate in such a hostile 
environment as the Cerrado will assist in current and future attempts to conserve (and even reintroduce) this rare and threatened species.

\section{Materials and Methods}

\section{Isolation and Testing of Rhizobia for Nodulation of $D$. wilsonii}

A pot experiment was set up to "trap" the symbiotic bacteria nodulating $D$. wilsonii. Seeds of $D$. wilsonii that had been scarified with sulphuric acid for 60 min were incubated in a germination chamber $\left(25^{\circ} \mathrm{C}\right)$ with a photoperiod of $12 \mathrm{~h}$ until they germinated. Pre-germinated seeds were then transplanted into pots filled with $2 \mathrm{~kg}$ of soil taken from the rhizosphere of 10 year old, nodulated D. wilsonii trees growing in a Cerrado site (Zoo-Botanical Garden, Belo Horizonte, MG, Brazil) (Figure 1A). A permit (\#5244138) for collection of soil and plant material from this site for research was obtained from the Instituto Brasileiro do Meio Ambiente e dos Recursos Naturais Renováveis (IBAMA), and was provided by the Sistema de Autorização e Informação em Biodiverside (SISBIO). The soil was characterized as a red-yellow Latosol, and it had low levels of nutrients, especially of phosphorus [59]. The experiment was performed in a greenhouse without supplemental light or temperature. Any nodules formed were harvested at $220 \mathrm{~d}$ after planting for isolation of rhizobia according to Somasegaran and Hoben [60], resulting in 22 isolates that might potentially be rhizobia based upon their growth rates and colony morphologies. These 22 isolates were then tested for their ability to nodulate $D$. wilsonii seedlings planted in sterilized soil in Leonard jars [61] according to [59] using $1 \mathrm{~mL}$ of a liquid culture of each isolate per jar $\left(10^{7} \mathrm{CFU} \mathrm{mL}^{-1}\right)$. The plants were harvested at 120 dai, and their biomass was determined as shoot dry weight.

The five best performing rhizobial isolates in terms of biomass production (isolates $3.1,6.4,8.5,10.1,12.5$ ) were then selected for further analysis of their nodulation and $\mathrm{N}_{2}$-fixing ability, but this time under $\mathrm{N}$-free conditions in pots filled with sterile sand and vermiculite. The experimental design was completely randomized with six treatments, consisting of an uninoculated control plus five different bacterial strains, with 3 replicates per treatment. Plants were examined visually every $30 \mathrm{~d}$ for the presence of root hairs, and were harvested at 120 dai. In order to test the ability of these strains to nodulate a crop legume commonly grown in the same environment in the state of Minas Gerais a similar Leonard Jar experiment was set using a commercial soybean (Glycine max L.) variety (BRSMG 68 Vencedora). Plants inoculated by B. elkanii strain $29 \mathrm{~W}$ were used as positive controls, and uninoculated plants served as negative controls. All plants were harvested at $60 \mathrm{~d}$ after inoculation.

\section{Light Microscopy and Transmission Electron Microscopy (TEM)}

A microscopical examination of the infection of $D$. wilsonii roots by rhizobial strains 10.1 and 12.5 was undertaken. Dimorphandra wilsonii seeds were surface-sterilized and germinated for $7 \mathrm{~d}$ in moisture chambers at room temperature and darkness. For longterm greenhouse experiments, seedlings were transferred to $2.5 \mathrm{~L}$ pots containing a sterile vermiculite and sand mixture $(1: 1 \mathrm{v} / \mathrm{v})$. After 28 d growth, each plant was inoculated with $50 \mathrm{ml}$ of a liquid suspension of strain 10.1 or strain $12.5\left(\mathrm{OD}_{600 \mathrm{~nm}} 0.5\right.$; $4 \times 10^{8}$ ) prepared in $\mathrm{N}$-free Fåhraeus medium [62]. Pots were watered as needed and fertilized once a week with Fåhraeus N-free complete nutrient solution. Plants were harvested at 42 and 63 dai, and intact roots and root-hair development, as well as any developing nodules, were examined using light microscopy and
TEM according to previous studies $[63,64]$. More detailed analyses to detect and localize in nodules the Fe-protein (nifH protein) of the nitrogenase enzyme complex by immunogold labeling coupled with TEM were performed using the methods described by dos Reis Junior et al. [65]. Furthermore, as it has long been considered that the PITs in caesalpinioid nodules are composed of plant cell wall material [7,10], TEM and immunogold labeling was also employed to localize a homogalacturonan epitope of the important cell wall component pectin by using the monoclonal antibody JIM5 (a gift from Dr N.J. Brewin, John Innes Centre, UK) which was originally used to demonstrate that the walls of infection threads in pea (Pisum sativum) nodules contained pectin [27]. Given that the nifH protein antibody was raised in rabbits and the JIM5 antibody was raised in rats it was also possible to perform a "double-labeling" immunogold experiment on mature nodules to determine if bacteroids expressing nifH protein were also surrounded by pectic material. Serial sections that were treated with non-immune serum substituted for either or both the nifH and JIM5 antibodies acted as negative controls [65].

The infection and development of nodules on $D$. jorgei was examined using the same basic methods as $D$. wilsonii, but with a few modifications to the sampling procedure. Briefly, nodules at various stages of development, from barely macroscopically visible "bumps" on roots to fully mature nodules, were sampled from plants at 60 dai with Bradyrhizobium sp. strain SEMIA6099, and then fixed and embedded for light microscopy and TEM as per $D$. wilsonii.

\section{Genotypic Characterization of Rhizobia Nodulating $D$. wilsonii}

The five isolates tested for nodulation of $D$. wilsonii and soybean were examined genetically by obtaining sequences of their rrs (16S rRNA), nodD and nifH genes as well as their 16S-23S internal transcribed spacer (ITS). The rrs gene of all five strains was amplified and sequenced according to Rivas et al. [66], and their 16S-23S rRNA ITS was amplified and sequenced as described by Willems et al. [35]. The nodD and nifH genes of strains were amplified with the primers described by Rivas et al. [67]; PCR conditions for both were preheating at $95^{\circ} \mathrm{C}$ for $5 \mathrm{~min}, 35$ cycles of denaturing at $95^{\circ} \mathrm{C}$ for $1 \mathrm{~min}$, annealing at $53^{\circ} \mathrm{C}$ for $1 \mathrm{~min}$ and extension at $72^{\circ} \mathrm{C}$ for $1 \mathrm{~min}$, and a final extension at $72^{\circ} \mathrm{C}$ for $7 \mathrm{~min}$. The sequences were obtained in an ABI3100 sequencer (Applied Biosystems Inc.) using a BigDye terminator v3.1 cycle sequencing kit as supplied by the manufacturer. The sequences obtained were compared with those from GenBank using the BLASTN program [68]. Sequences were aligned using the Clustal W software [69], and the distances were calculated according to Kimuras two-parameter method [70]. Phylogenetic trees were inferred using the maximum likelihood method [71], and the bootstrap analysis was based on 1000 resamplings. The MEGA 5 package [72] was used for all analyses. All identity values were calculated by pairwise analysis and gaps were not considered.

\section{Supporting Information}

Figure S1 Maximum likelihood phylogenetic tree based on nodD gene sequences (519 nt) showing the position of strains isolated from Dimorphandra wilsonii nodules compared with other rhizobial strains isolated from nodules of different legumes. Bootstrap values were calculated for 1000 replications. Bar, 5 nt substitution per $100 \mathrm{nt}$.

(PDF)

Figure S2 Maximum likelihood phylogenetic tree based on the nifH gene (381 nt) showing the position of strains isolated from 
Dimorphandra wilsonii nodules compared with other rhizobial strains isolated from nodules of different legumes. Bootstrap values were calculated for 1000 replications. Bar, 2 nt substitution per $100 \mathrm{nt}$. (PDF)

\section{Acknowledgments}

We would like to thank F.M Fernandes for providing D. wilsonï photos and to Fundação Zoo-Botânica for logistical assistance. We also thank IBAMA for permission to collect plant and soil material, and FMS Moreira for discussions.

\section{References}

1. Lewis GP, Schrire B, Mackinder, Lock M (2005) Legumes of the world. Kew: Royal Botanic Gardens. 592pp.

2. Sprent JI (2009) Legume nodulation. A global perspective. Chichester: WileyBlackwell. $183 \mathrm{p}$

3. Parker MA (2000) Divergent Bradyrhizobium symbionts on Tachigali versicolor from Barro Colorado Island, Panama. Syst Appl Microbiol 23: 585-590.

4. Diabate M, Munive A, Faria SM de, Ba A, Dreyfus B, et al. (2005) Occurrence of nodulation in unexplored leguminous trees native to the West African tropical rainforest and inoculation response of native species useful in reforestation. New Phytol 166: 231-239.

5. Faria SM de, Diedhiou AG, Lima HC de, Ribeiro RD, G, Castilho AF, et al. (2010) Evaluating the nodulation status of leguminous species from the Amazonian forest of Brazil. J Exp Bot 61: 3119-3127.

6. Sprent JI (2007) Evolving ideas of legume evolution and diversity: a taxonomic perspective on the occurrence of nodulation. New Phytol 174: 11-25.

7. Faria SM de, McInroy SG, Sprent JI (1987) The occurrence of infected cells, with persistent infection threads, in legume root nodules. Can J Bot 65: 553-558.

8. Sprent JI, James EK (2007) Legume evolution: Where do nodules and mycorrhizas fit in? Plant Physiol 144: 575-581.

9. Manoury N, Kondorosi A, Kondorosi E, Mergaert P (2008) Cell biology of nodule infection and development. In: Dilworth MJ, James EK, Sprent JI, Newton WE, editors. Nitrogen-fixing legume symbioses. Dordrecht: Springer. 153-189.

10. Naisbitt T, James EK, Sprent JI (1992) The evolutionary significance of the genus Chamaecrista, as determined by nodule structure. New Phytol 122: 487492.

11. Lima HC de (2010) Dimorphandra in Lista de Espécies da Flora do Brasil. Jardim Botânico do Rio de Janeiro. Available: http://floradobrasil.jbrj.gov.br/ 2010/FB030996. Accessed 14 October 2012.

12. Rizzini CT (1969) Espécies novas de árvores do planalto central brasileiro. Acad Bras Ciênc 41: 239-244.

13. Ratter JA, Ribeiro JF, Bridgewater S (1997) The Brazilian Cerrado vegetation and threats to its biodiversity. Ann Bot 80: 223-230.

14. Rizzini CT, Matos Filho A de (1986) Espécies vegetais em extinção. Boletim da Sociedade Brasileira para a Conservação da Natureza 21: 99-104.

15. Fernandes FM, Fonseca AG, Kaechele K, Goulart MF, Marinho W, et al. (2007) Tentando evitar mais uma extinção: o caso do Faveiro de Wilson (Dimorphandra wilsonii Rizz.). In: Sampaio T, Costa MLMN, Jackson PW, editors. Recuperando o verde para as cidades - a experiência dos Jardins Botânicos Brasileiros. Investing in Nature - Brasil. Rio de Janeiro: Rede Brasileira de Jardins Botânicos. 87-98.

16. IUCN (2006) IUCN Red List of Threatened Species. Available: http://www. iucnredlist.org. Accessed 14 October 2012.

17. Graham PH (2008) Ecology of the root-nodule bacteria of legumes. In: Dilworth MJ, James EK, Sprent JI, Newton WE, editors. Nitrogen-fixing legume symbioses. Dordrecht: Springer. 23-58.

18. Velázquez E, García-Fraile P, Ramírez-Bahena MH, Rivas R, Martínez-Molina $\mathrm{E}$ (2010) Bacteria involved in nitrogen-fixing legume symbiosis: Current taxonomic perspective. In: Khan MS, Zaidi A, Musarrat J editors. Microbes for Legume Improvement. Dordrecht: Springer. 1-25.

19. Gyaneshwar P, Hirsch AM, Moulin L, Chen W-M, Elliott GN, et al. (2011) Legume nodulating $\beta$-proteobacteria: diversity, host range and future prospects. Mol Plant Microbe Interact 24: 1276-1288.

20. Franco AA, de Faria SM (1997) The contribution of $\mathrm{N}_{2}$-fixing tree legumes to land reclamation and sustainability in the tropics. Soil Biol Biochem 29: 897903.

21. Germano MG, Menna P, Mostasso FL, Hungria M (2006) RFLP analysis of the rRNA operon of a Brazilian collection of bradyrhizobial strains from 33 legume species. Int J Syst Evol Microbiol 56: 217-229.

22. Binde DR, Menna P, Bangel EV, Barcellos FG, Hungria M (2009) rep-PCR fingerprinting and taxonomy based on the sequencing of the $16 \mathrm{~S}$ rRNA gene of 54 elite commercial rhizobial strains. Appl Microbiol Biotechnol 83: 897-908.

23. Menna P, Barcellos FG, Hungria M (2009) Phylogeny and taxonomy of a diverse collection of Bradyrhizobium strains based on multilocus sequence analysis of the $16 \mathrm{~S}$ rRNA gene, ITS region and $g \ln I I, r e c A, a t p D$ and $d n a K$ genes. Int J Syst Evol Microbiol 59: 2934-2950.

\section{Author Contributions}

Conceived and designed the experiments: EKJ MRS AP EV MBF PFM LPR SMdF JIS. Performed the experiments: MBF EKJ AP EV MRS SMdF LPR PFM CG. Analyzed the data: AP EKJ EV MBF PFM CG MRS JIS LPR RMdSI MGCF JLSA SMdF. Contributed reagents/ materials/analysis tools: AP EKJ MBF PFM CG EV MRS RMdSI MGCF JLSA SMdF. Wrote the paper: EKJ AP JIS EV PFM MRS.

24. Moreira FMS, Haukka K, Young JPW (1998) Biodiversity of rhizobia isolated from a wide range of forest legumes in Brazil. Mol Ecol 7: 889-895.

25. OBrien TP, McCully ME (1981) The study of plant structure principles and selected methods. Wantirna: Termarcarphi Pty Ltd. 342 p.

26. Perrineau M-M, Galiana A, de Faria SM, Bena G, Duponnois R, et al. (2012) Monoxenic nodulation process of Acacia mangium (Mimosoideae, Phyllodineae) by Bradyrhizobium sp. Symbiosis 56: 87-95.

27. VandenBosch KA, Bradley DJ, Knox JP, Perotto S, Butcher GW, et al. (1989) Common components of the infection thread matrix and the intercellular space identified by immunocytochemical analysis of pea nodules and uninfected roots. EMBO J 8: 335-342.

28. Lafay B, Burdon JJ (2007) Molecular diversity of legume root-nodule bacteria in Kakadu National Park, Northern Territory, Australia. PLoS ONE 2: e277.

29. Parker MA (2000) Divergent Bradyrhizobium symbionts on Tachigali versicolor from Barro Colorado Island, Panama. Syst Appl Microbiol 23: 585-590.

30. Lafay B, Bullier E, Burdon JJ (2006) Bradyrhizobia isolated from root nodules of Parasponia (Ulmaceae) do not constitute a separate coherent lineage. Int J Syst Evol Microbiol 56: 1013-1018.

31. Chahboune R, Carro, Peix A, Ramirez-Bahena M-H, Barrijal S, et al. (2012) Bradyrhizobium rifense sp. nov. isolated from effective nodules of Cytisus villosus grown in the Moroccan Rif. Syst Appl Microbiol 35: 302-305.

32. Islam MS, Kawasaki H, Muramatsu Y, Nakagawa Y, Seki T (2008) Bradyrhizobium iriomotense sp. nov., isolated from a tumor-like root of the legume Entada koshunensis from Iriomote Island in Japan. Biosci Biotechnol Biochem 72: 1416-29.

33. Zhang Y, Li Y, Chen WF, Wang ET, Sui X, et al. (2011) Bradyrhizobium huanghuaihaiense sp. nov., an effective symbiotic bacterium isolated from soybean (Glycine max L.) nodules in Northern (Huang-Huai-Hai) Plain of China. Int J Syst Evol Microbiol 62: 1951-1957.

34. Parker MA, Kennedy DA (2006) Diversity and relationships of bradyrhizobia from legumes native to eastern North America. Can J Microbiol 52: 1148-1157.

35. Willems A, Munive A, de Lajudie P Gillis M (2003) In most Bradyrhizobium groups sequence comparison of $16 \mathrm{~S}-23 \mathrm{~S}$ rDNA internal transcribed spacer regions corroborates DNA-DNA hybridizations. Syst Appl Microbiol 26: 203210.

36. Ormeño-Orrillo E, Rogel-Hernández MA, Lloret L, López-López A, Martínez $\mathrm{J}$, et al. (2011) Change in land use alters the diversity and composition of Bradyrhizobium communities and led to the introduction of Rhizobium etli into the Tropical Rain Forest of Los Tuxtlas (Mexico). Microb Ecol 63: 822-834.

37. Chang YL, Wang JY, Wang T, Liu HC, Sui XH, et al. (2011) Bradyrhizobium lablabi sp. nov., isolated from effective nodules of Lablab purpureus and Arachis hypogaea. Int J Syst Evol Microbiol. 61: 2496-2502.

38. Ramírez-Bahena MH, Peix A, Rivas R, Camacho M, Rodríguez-Navarro DN, et al. (2009) Bradyrhizobium pachyrhizi sp. nov. and Bradyrhizobium jücamae sp. nov., isolated from effective nodules of Pachyrhizus erosus. Int J Syst Evol Microbiol 59: 1929-34.

39. Scott KF (1986) Conserved nodulation genes from the non-legume symbiont Bradyrhizobium sp. (Parasponia). Nucleic Acid Res 14: 2905-2919.

40. Sprent JI (2001) Nodulation in legumes. Kew: Royal Botanic Gardens. 146 p.

41. Newcomb W, Sippel D, Peterson RL (1979) The early morphogenesis of Glycine max and Pisum sativum root nodules. Can J Bot 57: 2603-2616.

42. White J, Prell J, James EK, Poole P (2007) Nutrient sharing between symbionts. Plant Physiol 144: 604-614.

43. Vega-Hernández MC, Pérez-Galdona R, Dazzo FB, Jarabo-Lorenzo A, Alfayate MC, et al. (2001) Novel infection process in the indeterminate root nodule symbiosis between Chamaecytisus proliferus (tagasaste) and Bradyrhizobium sp. New Phytol 150: 707-721.

44. González-Sama A, Lucas MM, de Felipe MR, Pueyo JJ (2004) An unusual infection mechanism and nodule morphogenesis in white lupin (Lupinus albus). New Phytol 163: 371-380.

45. Trinick MJ (1979) Structure of nitrogen-fixing nodules formed by Rhizobium on roots of Parasponia andersonii Planch. Can J Microbiol 25: 565-578.

46. Smith CA, Skvirsky RC, Hirsch AM (1985) Histochemical evidence for the presence of a suberinlike compound in Rhizobium-induced nodules of the nonlegume Parasponia rigida. Can. F. Bot. 64: 1474-1483.

47. Op den Camp RHM, Polone E, Fedorova E, Roelofsen W, Squartini A, et al. (2012) Nonlegume Parasponia andersonii deploys a broad Rhizobium host range 
strategy resulting in largely variable symbiotic effectiveness. Mol Plant Microbe Interact 25: 954-963.

48. Moulin L, Béna G, Boivin-Masson C, Stepkowski T (2004) Phylogenetic analyses of symbiotic nodulation genes support vertical and lateral gene co-transfer within the Bradyrhizobium genus. Mol Phylogenet Evol 30: 720-732.

49. Stepkowski T, Hughes CE, Law IJ, Markiewicz L, Gurda D, et al. (2007) Diversification of lupine Bradyrhizobium strains: evidence from nodulation gene trees. Appl Environ Microbiol 73: 3254-3264.

50. Steenkamp ET, Stepkowski T, Przymusiak A, Botha WJ, Law IJ (2008) Cowpea and peanut in southern Africa are nodulated by diverse Bradyrhizobium strains harboring nodulation genes that belong to the large pantropical clade common in Africa. Mol Phylogenet Evol 48: 1131-1144.

51. Bontemps C, Elliott GN, Simon MF, dos Reis Junior FB, Gross E, et al. (2010) Burkholderia species are ancient symbionts of legumes. Mol Ecol 19: 44-52.

52. Simon MF, Grether R, Queiroz LP, Skema C, Pennington RT, et al. (2009) Recent assembly of the Cerrado, a neotropical plant diversity hotspot, by in situ evolution of adaptations to fire. PNAS 106: 20359-20364.

53. Moreira FMS, Gillis M, Pot B, Kersters K, Franco AA (1993) Characterization of rhizobia isolated from different divergence groups of tropical Leguminosae by comparative polyacrylamide gel electrophoresis of their total proteins. Syst Appl Microbiol 16: 135-146.

54. Han SZ, Wang ET, Chen WX (2005) Diverse bacteria isolated from root nodules of Phaseolus vulgaris and species within the genera Campylotropis and Cassia grown in China. Syst Appl Microbiol 28: 265-276.

55. Gupta RS, Mok A (2007) Phylogenomics and signature proteins for the alpha Proteobacteria and its main groups. BMC Microbiol 7: 106.

56. Martinez-Romero E (2009) Coevolution in Rhizobium-legume symbiosis? DNA Cell Biol 28: 361-370.

57. Bonaldi K, Gargani D, Prin Y, Fardoux J, Gully D, et al. (2011) Nodulation of Aeschynomene afraspera and $A$. indica by photosynthetic Bradyrhizobium sp. strain ORS285: the Nod-dependent versus the Nod-independent symbiotic interaction. Mol Plant Microbe Interact 24: 1359-1371.

58. Doyle JJ (2011) Phylogenetic perspectives on the origins of nodulation. Mol Plant Microbe Interact 24: 1289-1295.

59. Fonseca MB, França MGC, Zonta E, Giorni V (2010) Crescimento inicial de Dimorphandra wilsonii (Fabaceae - Gaesalpinioideae) em diferentes condições de fertilidade em solo de cerrado. Acta Bot Bras 24: 322-327.
60. Somasegaran P, Hoben HJ (1994) Methods in legume-Rhizobium Technology. New York: Springer. 450 p.

61. Vincent JM (1970) A manual for the practical study at root-nodule bacteria. Oxford: Blackwell. 150p.

62. Fåhraeus G (1957) The infection of clover root hairs by nodule bacteria studied by a simple glass slide technique. J Gen Microbiol. 16: 374-381.

63. Chen W-M, James EK, Prescott AR, Kierans M, Sprent JI (2003) Nodulation of Mimosa spp. by the $\beta$-proteobacterium Ralstonia taiwanensis. Mol Plant Microbe Interact 16: 1051-1061.

64. Chen W-M, de Faria SM, Straliotto R, Pitard RM, Simões-Araùjo JL, et al. (2005) Proof that Burkholderia forms effective symbioses with legumes: a study of novel Mimosa-nodulating strains from South America. Appl Environ Microbiol 71: 7461-7471.

65. dos Reis Junior FB, Simon MF, Gross E, Boddey RM, Elliott GN, et al. (2010) Nodulation and nitrogen fixation by Mimosa spp. in the Cerrado and Caatinga biomes of Brazil. New Phytol 186: 934-946.

66. Rivas R, García-Fraile P, Mateos PF, Martínez-Molina E Velázquez E (2007) Characterization of xylanolytic bacteria present in the bract phyllosphere of the date palm Phoenix dactylifera. Lett Appl Microbiol 44: 181-187.

67. Rivas R, Velázquez E, Willems A, Vizcaíno N, Subba-Rao NS, et al. (2002) A new species of Devosia that forms a nitrogen-fixing root-nodule symbiosis with the aquatic legume Neptunia natans (L. f.) Druce. Appl Environ Microbiol 68: 52175222

68. Altschul SF, Gish W, Miller W, Myers EW, Lipman DJ (1990) Basic local alignment search tool. J Mol Biol 215: 403-410.

69. Thompson JD, Gibson TJ, Plewniak F, Jeanmougin F, Higgins DG (1997) The clustalX windows interface: flexible strategies for multiple sequence alignement aided by quality analysis tools. Nucleic Acid Res 24: 4876-4882.

70. Kimura M (1980) A simple method for estimating evolutionary rates of base substitutions through comparative studies of nucleotide sequences. J Mol Evol 16: $111-120$.

71. Felsenstein J (1981) Evolutionary trees from DNA sequences: a maximum likelihood approach. J Mol Evol 17: 368-376.

72. Tamura K, Peterson D, Peterson N, Stecher G, Nei M, et al. (2011) MEGA5: Molecular evolutionary genetics analysis using Maximum Likelihood, Evolutionary Distance, and Maximum Parsimony methods. Mol Biol Evol 4: 27312739 . 